\title{
Honoré de Balzac, Teoria del camminare
}

\section{Marco Stupazzoni}

\section{(2) OpenEdition}

\section{Journals}

\section{Edizione digitale}

URL: http://journals.openedition.org/studifrancesi/1385

DOI: 10.4000/studifrancesi. 1385

ISSN: 2421-5856

\section{Editore}

Rosenberg \& Sellier

\section{Edizione cartacea}

Data di pubblicazione: 1 décembre 2015

Paginazione: 607

ISSN: 0039-2944

\section{Notizia bibliografica digitale}

Marco Stupazzoni, «Honoré de Balzac, Teoria del camminare», Studi Francesi [Online], 177 (LIX | III) |

2015, online dal 01 décembre 2015, consultato il 07 janvier 2021. URL: http://

journals.openedition.org/studifrancesi/1385; DOI: https://doi.org/10.4000/studifrancesi.1385

Questo documento è stato generato automaticamente il 7 janvier 2021.

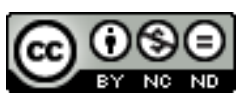

Studi Francesi è distribuita con Licenza Creative Commons Attribuzione - Non commerciale - Non opere derivate 4.0 Internazionale. 


\title{
Honoré de Balzac, Teoria del camminare
}

\author{
Marco Stupazzoni
}

\section{NOTIZIA}

HONORÉ DE BALZAC, Teoria del camminare, traduzione di Carla QUERCIA, Roma, Ellint, 2014, «Lampi», pp. 89.

1 Segnaliamo la pubblicazione di questa nuova traduzione italiana de La Théorie de la démarche, opera edita tra l'agosto e il settembre $1833 \mathrm{su}$ «L'Europe littéraire». Questo testo costituisce una delle colonne portanti (insieme al Traité de la vie élégante e al Traité des excitants modernes) della Pathologie de la vie sociale all'interno delle Études analytiques.

2 Il saggio balzachiano, che, a giudizio di Rose Fortassier (cf. introduction alla Pathologie de la vie sociale, Paris, «Nouvelle Pléiade», 1981, t. XII, p. 197), «apparaît en quelque sorte comme la version laïque, mondaine, journalistique de Louis Lambert, comme la vulgarisation d'une pensée ésotérique», affronta, in realtà, tematiche importanti e profonde che appartengono al pensiero filosofico e metafisico di Balzac e che si ritrovano espresse in romanzi quali La Peau de chagrin e, appunto, Louis Lambert. 